\title{
New Agromyza Fallén (Diptera, Agromyzidae) from Brazil and a key for the Neotropical species
}

\author{
VIVIANE R. DE SOUSA and MÁRCIA S. COURI \\ Departamento de Entomologia, Museu Nacional, Universidade Federal do Rio de Janeiro, \\ Quinta da Boa Vista, s/n, São Cristóvão, 20940-040 Rio de Janeiro, RJ, Brasil
}

Manuscript received on April 13, 2016; accepted for publication on May 26, 2016

\begin{abstract}
Agromyza Fallén (Diptera, Agromyzidae) is a genus of leaf mining flies, including species with high economic importance. The knowledge of this genus is very poor in the neotropics, with 12 known species, only six of them recorded from Brazil. This paper describes two new Agromyza species from "Cerrado" and "Pantanal" biomes and records three other species represented only by females that could not be identified to species level. We also present a taxonomic key to segregate the 14 Neotropical species. The specimens were collected in Mato Grosso and Mato Grosso do Sul states and are deposited at Museu de Zoologia, Universidade de São Paulo (São Paulo, Brazil) and Museu Nacional, Universidade Federal do Rio de Janeiro (Rio de Janeiro, Brazil) collections. The adults were photographed and the male terminalia were dissected and illustrated.
\end{abstract}

Key words: Leaf mining flies, morphology, new species, taxonomy.

\section{INTRODUCTION}

The species of Agromyza Fallén (Diptera, Agromyzidae) are mostly leaf miners, with a few known as agricultural pests, known to attack a wide variety of cereals such as barley, oats, rye, wheat and corn (Spencer 1973a). Some species are galling, such as the Brazilian A. terebrans Bezzi and Tavares, 1916 that induces galls on leaves of Clitoria laurifolia Poir (Fabaceae) (Zlobin 2000). A considerable number of species are associated with a variety of dicotyledonous as host-plants, including Betulaceae, Boraginaceae and Asteraceae (see Benavent-Corai et al. 2005), although many

Correspondence to: Viviane Rodrigues de Sousa

E-mail: sousavrodrigues@gmail.com species also occurs in monocotyledons. One particularly diverse group with characteristic male genitalia are found on numerous genera of grasses (Spencer 1990). Another group named the orobi-group includes species that feed on Fabaceae (Zlobin 2000).

Agromyza species are morphologically similar to Phytobia Lioy species, especially in the course of the Subcostal vein (Spencer and Steyskal 1986), but the presence of a stridulatory mechanism on the abdomen of both sexes in Agromyza can segregate these two genera (Tschirnhaus 1971). This stridulatory mechanism is present on the anterior lateral margin of the tergites $1+2$ and on the posterior margin of the hind femur (Boucher 2010) and is one of the apomorphies that support the monophyly of the genus (Scheffer et al. 2007). 
The other characters of the genus are very variable, although the following diagnosis is generally accepted: Costal vein ending at vein $R_{4+5}$ or continuing to $\mathrm{M}_{1+2}$; dm-cu crossvein present; Subcostal vein complete, joining vein $\mathrm{R}_{1}$ before reaching the Costal vein; haltere white or yellow (black in A. fusca Spencer, 1963); orbital setulae reclinate; gena angulate, deepest at rear; usually at least 3 or 4 distinct dorsocentral setae (presuturals sometimes weak or absent); prescutelar present; general color of the body black or partly yellow, without metallic sheen; wing length 2-4 $\mathrm{mm}$ and rarely infuscate (except in A. fusca) (Spencer and Steyskal 1986, Boucher 2010).

The number of Agromyza species in the world is around 200 (Boucher 2010), 12 of them recorded from the Neotropical region and only six known from Brazil (Martinez and Etienne 2002). The singular species $A$. fusca, with an infuscated wing, described from Brazil (Spencer 1963) is also recorded from Dominica (Spencer and Stegmaier Jr 1973) and was registered in Guadeloupe causing mines in Ichnanthus pallens (Sw.) (Poaceae) (Etienne and Martinez 2003).

This paper describes two new species of Agromyza found in Mato Grosso and Mato Grosso do Sul, in "Cerrado" and "Pantanal" biomes respectively. We also present an illustrated key for the Neotropical species.

The ZooBank Life Science Identifier (LSID) of this publication is: urn:lsid:zoobank.org:pub: 069EA140-2C09-4538-B25C-1C8D01727B2D.

\section{MATERIALS AND METHODS}

The specimens of the new species herein described were collected in Mato Grosso and Mato Grosso do Sul states (Brazil), in areas of "Cerrado", "Pantanal" biomes respectively, where the agromyzid fauna is almost unknown. The collections occurred during periodic expeditions of the "SISBIOTA Diptera" project, during the years of 2011-2013.
The specimens were captured using Malaise traps, preserved in $98 \%$ alcohol and mounted on entomological pins. Male terminalia were clarified in $\mathrm{KOH} 10 \%$ for 48 hours, immerse in glycerin on blades for analysis under optical microscope and drawn using a camera lucida.

Besides the material herein described, five females belonging to three other species were collected, but the identification could not be confirmed without the males.

Digital images were made using a Leica MZ16 stereomicroscope and the software AutoMontage Pro by Syncroscopy, version 5.03.0061. The terminology used followed Cumming and Wood (2009) and Boucher (2010). The map was made using DIVA-gis. The material is deposited at the collections of Museu de Zoologia, Universidade de São Paulo (MZUSP, São Paulo, Brazil) and Museu Nacional, Universidade Federal do Rio de Janeiro (MNRJ, Rio de Janeiro, Brazil).

We also included in the Taxonomy topic, data on all known Neotropical species which were also keyed.

\section{Acronyms used for the location of the types:}

BMNH - The Natural History Museum, London, England

CAS - California Academy of Sciences, San Francisco, California, USA

DEI - Deutsches Entomologisches Institut, Eberswalde, Germany

MCZ - Museum of Comparative Zoology, Harvard University Cambridge, Massachusetts, USA

NMNH - National Museum of Natural History, Washington D.C., USA

\section{RESULTS}

\section{Taxonomy}

Agromyza animata Spencer, 1973b Holotype male (DEI); Martinez and Etienne 2002: 27 (list).

Notes: Host-plant: unknown

Known geographical distribution: Costa Rica 
Agromyza apfelbecki Strobl, 1902 Syntype male, female (coll. Strolb, Austria); Hendel 1931-1936: 107; Spencer 1963: 295 (key, recorded from Chile); Spencer 1967: 83.2 (catalogue); Spencer 1973a: 148 (redescription, Figs 208-213); Valladares 1998: 105 (redescription, Figs 1-2 and recorded from Argentina); Martinez and Etienne 2002: 27 (list); Civelek et al. 2009: 251 (recorded from Turkey); Gil-Ortiz et al. 2010: 309 (geographical distribution and host-plant).

Agromyza abiens Zetterstedt, 1848: 2747 var. apfelbecki; Spencer 1963: 295 (synonymic list); Valladares 1998: 105 (synonymic list).

Agromyza andalusiaca Strolb, 1906: 380; Spencer 1963: 295 (synonymic list); Valladares 1998: 105 (synonymic list).

Notes: Host-plants: Carduus L., Cirsium Mill., Cynara cardunculus L., Cynara scolymus, L., Cynara baetica (Spreng.) Pau (all Asteraceae)

Known geographical distribution: Argentina, Chile, Palaearctic region, Turkey

Agromyza corumbensis sp. nov. (Figs 1, 2, 4-6)

ZooBank Life Science Identifier (LSID) urn:1sid:zoobank.org:act: EA46C50C-121E-4552A5FD-755C16F640E7
Type material: Holotype male: BRASIL: MS [Mato Grosso do Sul]: Corumbá, BEP Paratudal. S 19³4'11.04" W 5701'08.5”, Malaise 01, 0116.viii.2012. Lamas, Nihei \& eq. cols. [MZUSP], Paratype male: one, same data as holotype [MNRJ] (Fig. 1).

Etymology: The specific name is a reference to the type locality.

Description: Male. Body length: $1.6 \mathrm{~mm}$; wing length: $1.4 \mathrm{~mm}$ (Fig. 2)

Color. Frons dark brown; fronto-orbital plate and ocellar triangle weakly shining dark brown; lunule brown with grey pollinosity; face and gena dark brown; scape and pedicel dark brown, first flagellomere brown, light brown, ventrobasally; arista entirely brown; palpus brown, proboscis and labellum yellowish brown; scutum and all pleurae shining dark brown; haltere entirely white; calypters grey, with margin and fringe brown; wing clear; legs brown, with fore knee yellowish; pulvilli yellow; abdomen and terminalia entirely shining dark brown.

Head. Four pairs of fronto-orbitals, two ori inwards directed two ors backwards directed; orbital setulae reclinate in one row; eye height about 3.5 the gena

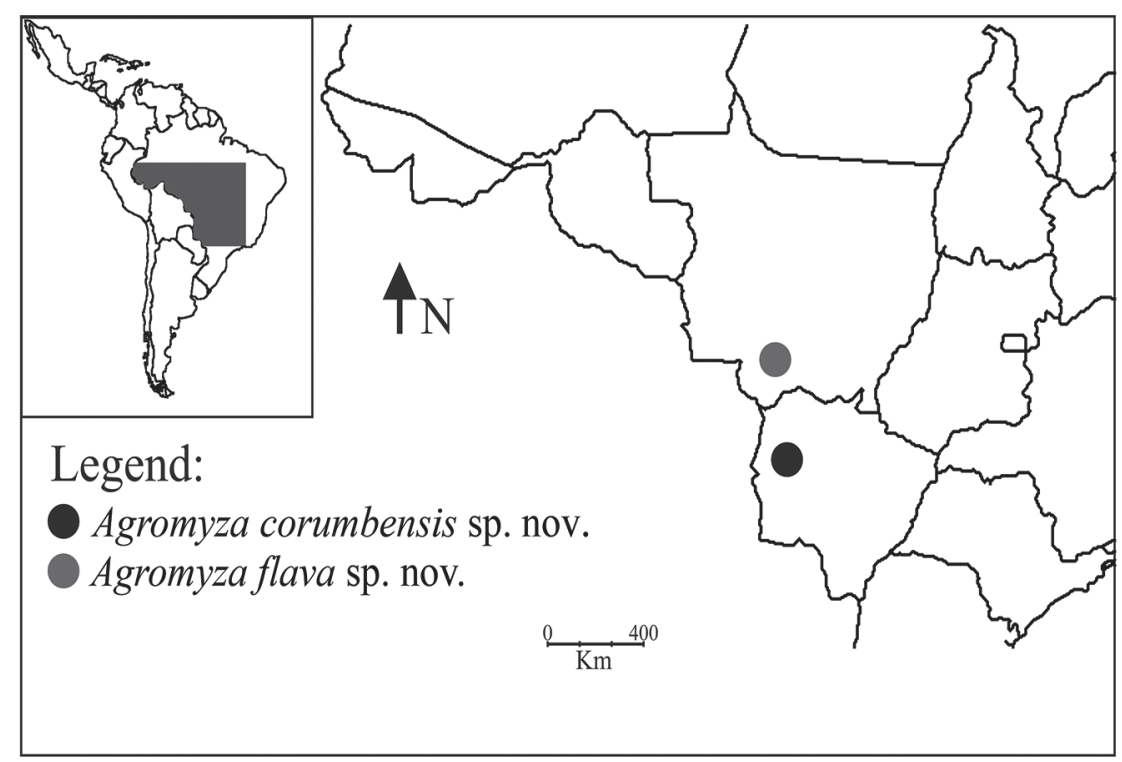

Figure 1 - Map with the collected localities of the new Agromyza Fallén species. 
height; ocellar triangle long, ending before the first ors; ocellar setae divergent and forward directed; first flagellomere slightly elongated and finely pubescent; arista long and pubescent; vibrissa strong.

Thorax. Acrostichals in six irregular rows; presutural dorsocentrals 1; postsutural dorsocentrals 3; 1 presutural and 1 postsutural long intra-alar seta; two supra-alar setae; one postalar seta; two long and strong pairs of scutellar setae, one sub-basal and one apical; two notopleural setae; length of ultimate section of vein $\mathrm{Cu}_{1}$ divided by the penultimate section: 1.2; vein $\mathrm{r}-\mathrm{m}$ at middle of cell $\mathrm{dm}$. Legs. Fore femur with a strong row of setae in the posterodorsal surface; mid and hind femora without differentiated setae; mid tibia with two posterodorsal setae on middle third and one strong apical ventral seta; hind tibia with one ventral apical seta.

Terminalia. Epandrium rounded, setulose and with long setae; cercus long, setulose with long setae; surstylus rounded with 8-13 large spines and 5-6 setae; hypandrium Y-shaped; phallapodeme about twice the length of the hypandrium; basiphallus with broadened sclerites at distal end; mesophallus short, asymmetric and measuring about half the size of the distiphallus; distiphallus cup-shaped with microscopic spines at apical two-thirds (Figs 4,5 ); ejaculatory apodeme rounded, at its broader part about 7.1 times wider than the constricted area at base (Fig. 6).

Female. Unknown

Host-plant. Unknown

Known geographical distribution. Mato Grosso do Sul (Brazil)

Comments. This species resembles Agromyza megaepistoma Sasakawa, 2005 known from El Salvador, in the general coloration of the body and wing size, however, can be distinguished, besides the characters in the key, by the number of dorsocentral setae $(1+3)$.

Agromyza flava sp. nov. (Figs 1, 3, 7-9)

ZooBank Life Science Identifier (LSID) urn:1sid:zoobank.org:act: E3EA29A8-BF06-4932943D-D9E96D62A34D

Type material: Holotype male: BRASIL: MT [Mato Grosso]: Poconé, Fazenda Rio Clarinho. S $16^{\circ} 26^{\prime} 21^{\prime \prime} \mathrm{W} 56^{\circ} 43^{\prime} 31.0^{\prime \prime}$, Light trap [armadilha
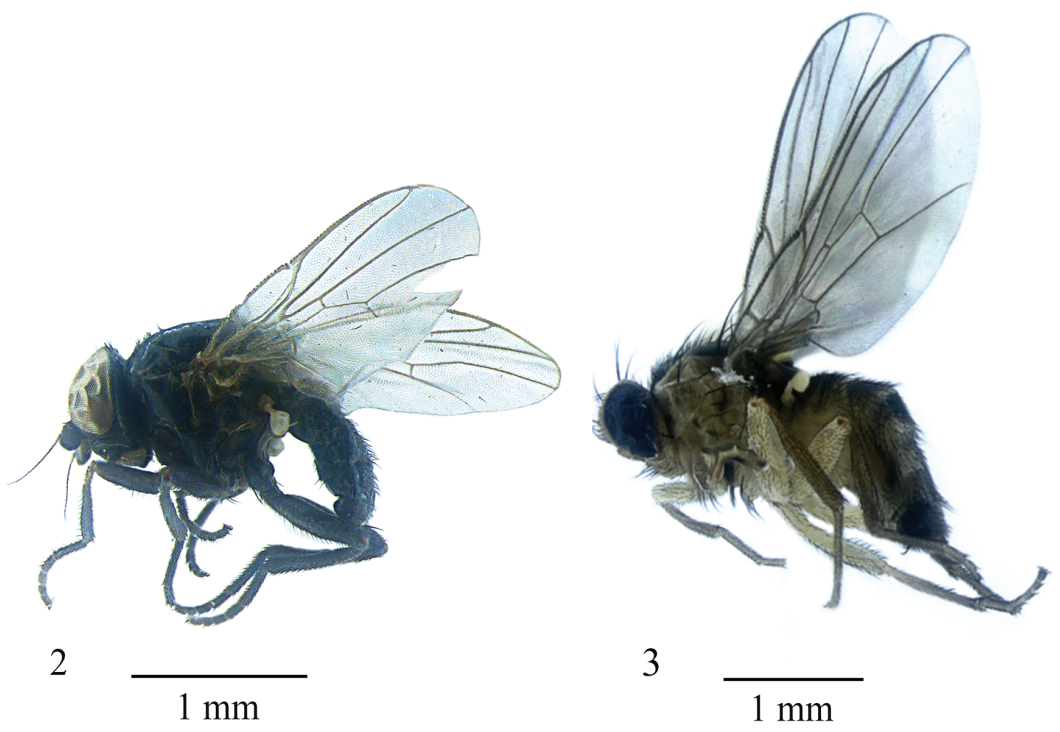

Figures (2-3) - Agromyza corumbensis sp. nov.: (2) adult male holotype, lateral view; Agromyza flava sp. nov.: (3) adult male holotype, lateral view. 
luminosa], 14.vii.2012. Lamas, C.J.B. \& eq. cols. [MZUSP] (Fig. 1).

Etymology: The epithet flava refers to yellow coloration of the body.

Description: Male. Body length: $2.4 \mathrm{~mm}$; wing length: $2.1 \mathrm{~mm}$ (Fig. 3)

Color. Frons and fronto-orbital plate yellow; ocellar triangle brown; lunule, face and gena yellow; antenna yellowish orange; arista entirely brown; palpus, proboscis and labellum yellow; scutum shining brown with a yellow area before scutellum; postpronotum yellow, with a small central brownish spot; notopleuron yellow; anepimeron brownish yellow; anepisternum yellow with three spots arranged diagonally; katepimeron yellow; katepisternum brown, yellow on superior
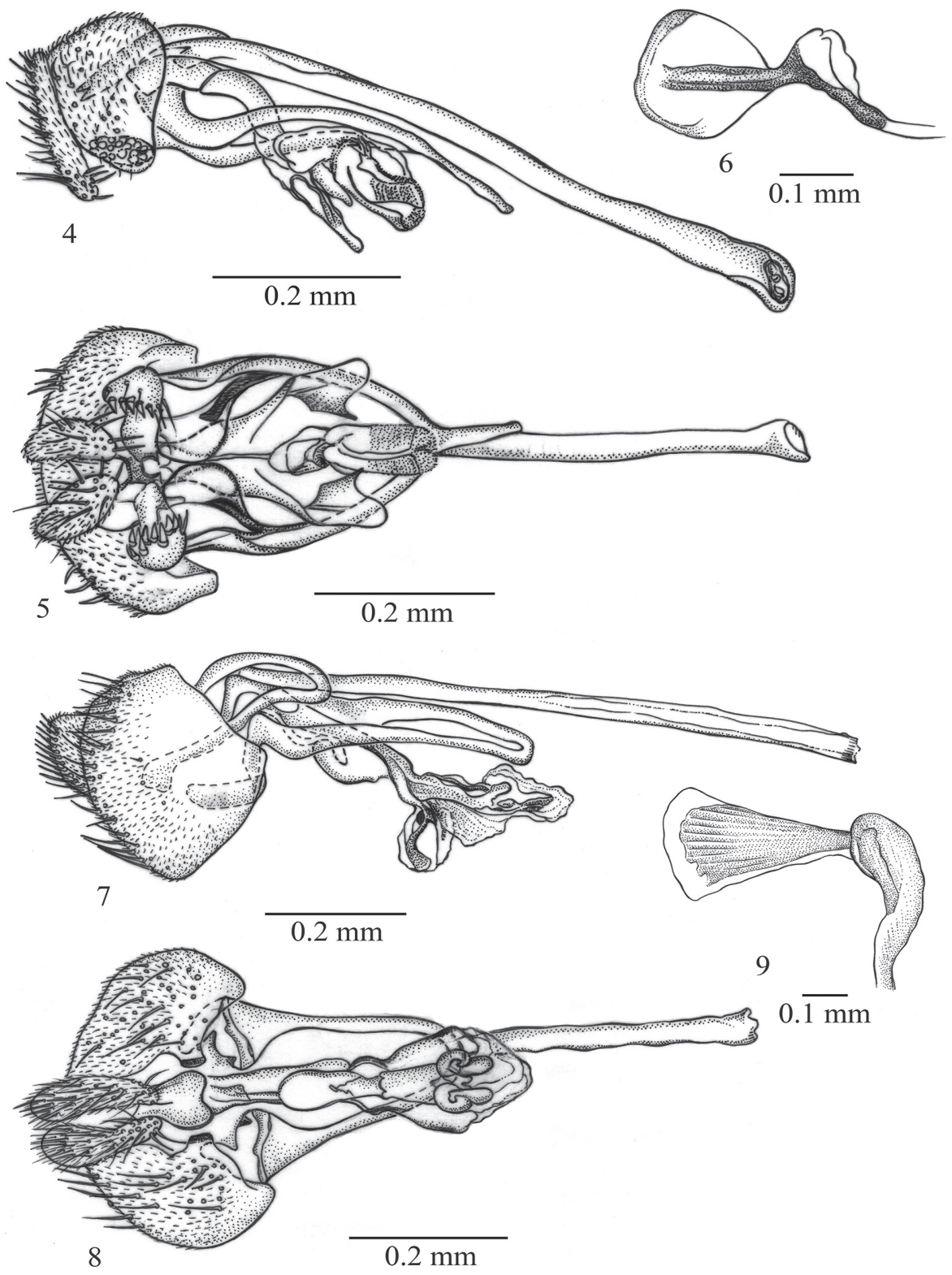

Figures (4-9) - Agromyza corumbensis sp. nov.: (4) phallus lateral view; (5) phallus ventral view; (6) ejaculatory apodeme lateral view. Agromyza flava sp. nov.: (7) phallus, lateral view; (8) phallus ventral view; (9) ejaculatory apodeme lateral view. 
part; meron brown, yellow around; haltere entirely yellow; calypters grey, with margin and fringe dark brown; wing clear; legs yellow with mid and hind tibiae and tarsi brownish yellow; pulvilli yellow; abdomen yellow, all tergites shining brown with superior and lateral margins yellow; terminalia entirely shining brown.

Head. Four pairs of fronto-orbital setae, two ori inwards directed, two ors backwards directed; orbital setulae reclinate in two irregulars rows; eye height about 4 times gena height; ocellar triangle short, ending before the second ors; ocellar setae divergent and forward directed; first flagellomere rounded and finely pubescent; arista long and plumose; vibrissa strong.

Thorax. Acrostichals in six irregular rows; prescutellars weak; presutural dorsocentrals 1; postsutural dorsocentrals $3 ; 1$ presutural and 1 postsutural long intra-alar seta; two supra-alar setae; one postalar seta; one postpronotal seta; two long and strong pairs of scutellar setae, one sub-basal and one apical; two notopleural setae, the anterior longer than the posterior; three anepisternal setae long and strong, the superior longer than the others; length of ultimate section of vein $\mathrm{CuA}_{1}$ divided by penultimate section: 1.6 ; vein $\mathrm{r}-\mathrm{m}$ slightly past midpoint of cell $\mathrm{dm}$.

Legs. Fore femur with a strong row of setae on the posterodorsal surface; mid and hind femora without differentiated setae; mid tibia with one posterodorsal seta on middle third and one strong apical ventral seta; hind tibia with one ventral apical seta.

Terminalia. Epandrium rounded, with two sclerotized lateral lobes, and with long setae; cercus long, setulose with long setae; surstylus elongated; hypandrium U-shaped; phallapodeme about twice the length of the hypandrium; basiphallus rounded; mesophallus long, bulb-shaped; distiphallus well sclerotized, forming a simple plate at base and bilobed at the apex, with a membrane surrounding it (Figs 7, 8); ejaculatory apodeme triangular, at its larger part about 4.5 times wider than the constricted area at base (Fig. 9).
Female. Unknown

Host-plant. Unknown

Known geographical distribution. Mato Grosso (Brazil)

Comments. The species runs to couplet 5 in the key herein presented and can be segregated from Agromyza simillima Spencer, 1963 by the morphology of the phallus. This species resembles the yellow Japanagromyza Sasakawa species, but the presence of the stridulatory mechanism confirms its position among the Agromyza.

Agromyza fusca Spencer, 1963 Holotype male (BMNH); Spencer 1967: 83.2 (catalogue); Spencer and Stegmaier Jr 1973: 139 (short notes, Figs male terminalia 324 and 325, recorded from Dominica); Martinez and Etienne 2002: 27 (list); Etienne and Martinez 2003: 250 (notes on host-plants and recorded from Guadeloupe).

Notes: Host-plant: Ichnanthus pallens (Poaceae)

Known geographical distribution: Brazil, Dominica, Guadeloupe

Agromyza insolens Spencer, 1963 Holotype male (BMNH); Spencer 1967: 83.2 (catalogue); Martinez and Etienne 2002: 27 (list).

Notes: Host-plant: unknown

Known geographical distribution: Brazil

Agromyza megaepistoma Sasakawa, 2005 Holotype male (CAS).

Notes: Host-plant: unknown

Known geographical distribution: El Salvador

Agromyza parvicornis Loew, 1869 Lectotype male (MCZ); Frick 1959: 356 (key, short notes and recorded from New York); Spencer 1966: 1 (short notes, Fig. male terminalia 1 and recorded from Florida); Spencer 1969: 51 (redescription and recorded from Canada); Spencer 1973a: 252 (redescription, Figs 370-373 and notes on economic importance); Spencer and Stegmaier Jr 1973: 18 (key, redescription and recorded from U.S.A.); 
Spencer and Steyskal 1986: 67 (key, diagnosis and Figs 417-419); Spencer 1990: 361 (geographical distribution and host-plants); Spencer et al. 1992: 270 (short notes and recorded from Guadeloupe); Valladares 1998: 106 (redescription, Figs 3-10 and recorded from Argentina); Martinez et al. 1993: 167 (notes and recorded from Dominican Republic); Martinez and Etienne 2002: 28 (list).

Notes: Host-plants: Echinochloa crus-galli (L.) P. Beauv., Panicum miliaceum L., Zea mays L. (all Poaceae).

Known geographical distribution: Argentina, Cuba, Canada, Dominican Republic, Guadeloupe, Puerto Rico, Saint-Vincent, U.S.A.

Agromyza plaumanni Spencer, 1963 Holotype male (BMNH); Spencer 1967: 83.2 (catalogue); Martinez and Etienne 2002: 28 (list).

Notes: Host-plant: unknown

Known geographical distribution: Brazil

Agromyza proxima Spencer, 1969 Holotype male (NMNH); Spencer and Stegmaier Jr 1973: 19 (key, redescription and recorded from U.S.A); Spencer and Steyskal 1986: 67 (key, diagnosis, Figs 421 and 422); Spencer 1990: 361 (geographical distribution and host-plants); Valladares 1998: 106 (redescription, Figs 11-13 and recorded from Argentina); Martinez and Etienne 2002: 28 (list).

Notes: Host-plants: Echinochloa walteri (Pursh) Heller, Echinochloa crus-galli, Panicum dichotomiflorum Michx. (all Poaceae).
Known geographical distribution: Argentina, Canada, U.S.A.

Agromyza serratimentula Sasakawa, 1992 Holotype male (CAS); Martinez and Etienne 2002: 28 (list).

Notes: Host-plant: unknown

Known geographical distribution: Brazil

Agromyza simillima Spencer, 1963 Holotype male (BMNH); Spencer 1967: 83.2 (catalogue); Martinez and Etienne 2002: 28 (list).

Notes: Host-plant: unknown

Known geographical distribution: Brazil

Agromyza terebrans Bezzi and Tavares, 1916 (sex?, location of type unknown); Spencer 1963: 300 (diagnosis); Spencer 1967: 83.2 (catalogue); Martinez and Etienne 2002: 28 (list).

Notes: Host-plant: Clitoria laurifolia Poir. (Fabaceae)

Known geographical distribution: Brazil

Agromyza venezolana Spencer, 1963 Holotype male (BMNH); Spencer 1967: 83.2 (catalogue); Spencer and Stegmaier Jr 1973: 139 (short notes, Fig. 327 and recorded from Bahamas, Costa Rica and Puerto Rico); Martinez and Etienne 2002: 28 (list).

Notes: Host-plant: unknown

Known geographical distribution: Bahamas, Costa Rica, Puerto Rico, Venezuela

Key to Neotropical species of Agromyza Fallén

\begin{tabular}{|c|c|}
\hline 1. & Scutum matt or matt grey..... \\
\hline- & Scutum shining................ \\
\hline 2. & $\begin{array}{l}\text { Frons reddish; wing } 3.4 \mathrm{~mm} \text { in male and } 4.2 \mathrm{~mm} \text { in female; calypters pale gray; } \\
\text { dorsocentrals variable, but normally } 4+2 \text { [surstylus with a patch of strong setae on } \\
\text { inner face; phallus as in Fig. 10]............................................... apfelbecki Strolb }\end{array}$ \\
\hline- & $\begin{array}{l}\text { Frons yellowish; wing with } 2.5-3.0 \mathrm{~mm} \text {; calypters yellow; dorsocentrals with } 2 \text { setae } \\
\text { [antenna yellowish with first flagellomere black].........A. terebrans Bezzi \& Tavares }\end{array}$ \\
\hline 3. & Arista plumose \\
\hline- & Arista bare or pubescent.......................... \\
\hline
\end{tabular}




\section{Key to Neotropical species of Agromyza Fallén (continuation)}

4. Haltere entirely dark brown [wing darkened in basal area (Fig. 11); dorsocentrals 0+3; hypandrium with side-arms conspicuously black (Fig. 12); phallus as in Figs 13 and 14].... A. fusca Spencer

- Haltere entirely yellow.

5

5. Body mostly brown; wing slightly darkened; dorsocentral $0+2$ with one smaller anterior one; prescutelars strong [ejaculatory apodeme distinctive with blade entirely reduced (Fig. 15); hypandrium with narrower side-arms and smaller postgonites (Fig. 16)]. A. simillima Spencer

- $\quad$ Body mostly yellow; wing clear; dorsocentral 1+3; prescutelars fine [surstylus elongated; hypandrium U-shaped; phallapodeme about twice the length of the hypandrium; basiphallus rounded; mesophallus long and bulb-shaped; distiphallus well sclerotized, forming a simple plate at base, bilobed at the apex, with a membrane surrounding it (Figs 7 and 8); ejaculatory apodeme triangular, at its broader part about 4.5 times wider than the constricted area at base (Fig. 9)].

Agromyza flava sp. nov.

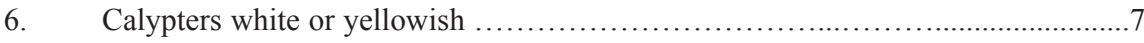

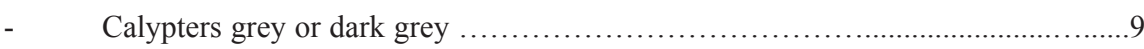

7. Dorsocentral 0+4-5 [surstylus with a group of some 15 spines on inner margin (Fig. 17); phallus with conspicuously short and broad distiphallus (Figs 18 and 19)]......

A. parvicornis Loew

- $\quad$ Dorsocentral $0+3$

8

8. Wing length in male $1.9 \mathrm{~mm}$ [phallus with distiphallus conspicuously short and broad (Figs 20 and 21)]... A. animata Spencer

- $\quad$ Wing length in male $2.4 \mathrm{~mm}$ [hypandrium with narrow, rounded side-arms and elongated hypandrial apodeme (Fig. 22); phallus as in Figs 23 and 24]....

A. venezolana Spencer

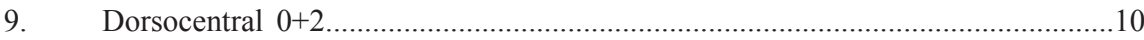

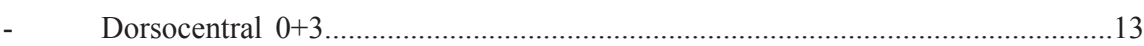

10. Arista bare [phallus with long relatively narrow distiphallus (Figs 25 and 26)]... A. proxima Spencer

- $\quad$ Arista pubescent . .11

11. Wing length in male $2.4 \mathrm{~mm}$; palpus pale brown [phallus subequal to hypandrium in length; basiphallus with a membranous, short and apically hairy process ventrally; distiphallus in distal tubules with rows of serrulate spinule on surface (Figs 27 and

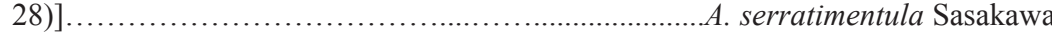

- $\quad$ Wing length in male 1.4 to $2.1 \mathrm{~mm}$; palpus brown or dark brown. . .12

12. Haltere yellow, with stalk faintly brown-tinged [surstylus with 12-14 spines (Fig. 29); hypandrium with short apodeme (Fig. 30); phallus nearly $1 / 2$ length of phallapodeme; basiphallus with sclerites broadened at distal ends; distiphallus densely hairy on outer side and spinulose internally (Figs 31 and 32)] A. megaepistoma Sasakawa

- $\quad$ Haltere entirely white [surstylus rounded with 8-13 large spines and 5-6 setae; hypandrium Y-shaped; phallapodeme about twice the length of the hypandrium; basiphallus with broadened sclerites at distal end; mesophallus short, asymmetrical and measuring about half the size of the distiphallus; distiphallus cup-shaped with microscopic spines at apical two thirds (Figs 4 and 5); ejaculatory apodeme rounded, at its broader part about 7.1 times wider than the constricted area at base (Fig. 6)] Agromyza corumbensis sp. nov.

13. Haltere darkened brownish-yellow, with knob yellow; wing length in male $2.5 \mathrm{~mm}$; hypandrium as in Fig. 33; distiphallus with elongate paired tubules (Figs 34 and 35

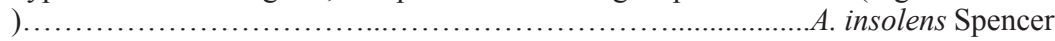

- $\quad$ Haltere entirely yellow; wing length in male $3.3 \mathrm{~mm}$; hypandrium as in Fig. 36; distiphallus rather long and slender (Fig. 37); [ejaculatory apodeme relatively large, blade asymmetrical (Fig. 38)]....................................A. plaumanni Spencer 

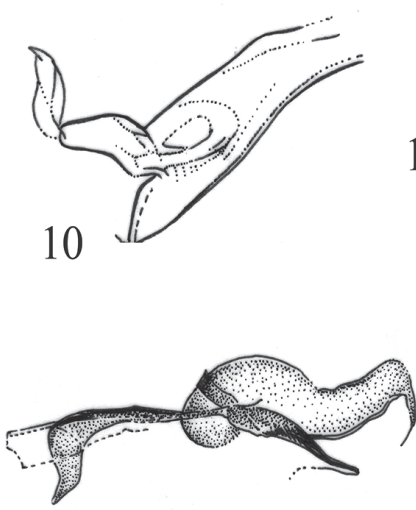

13
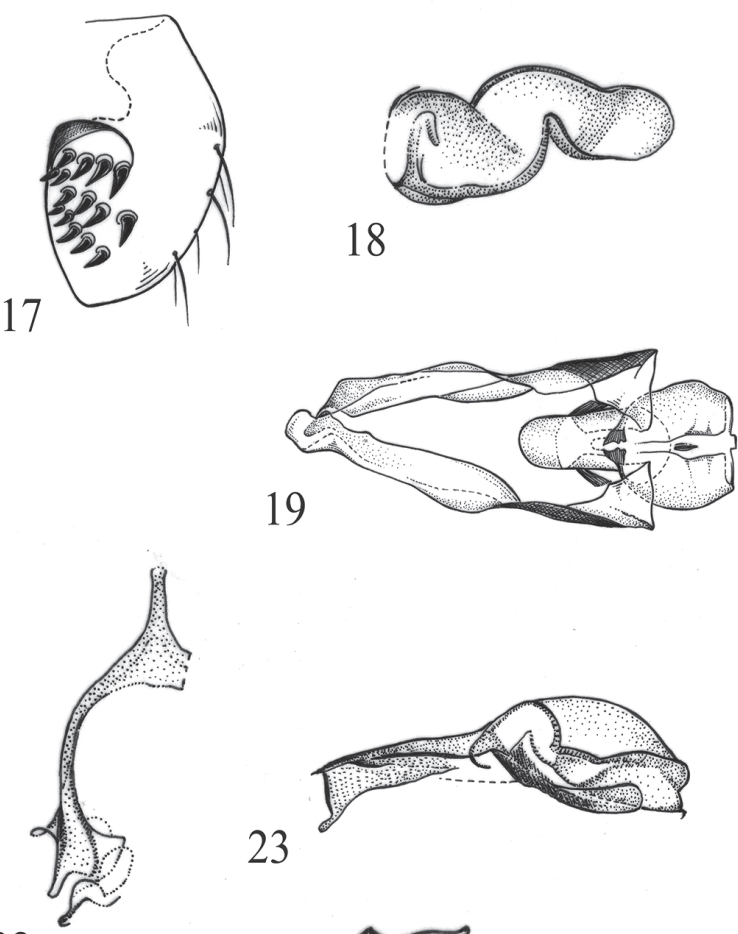

23

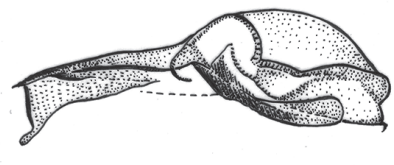

22
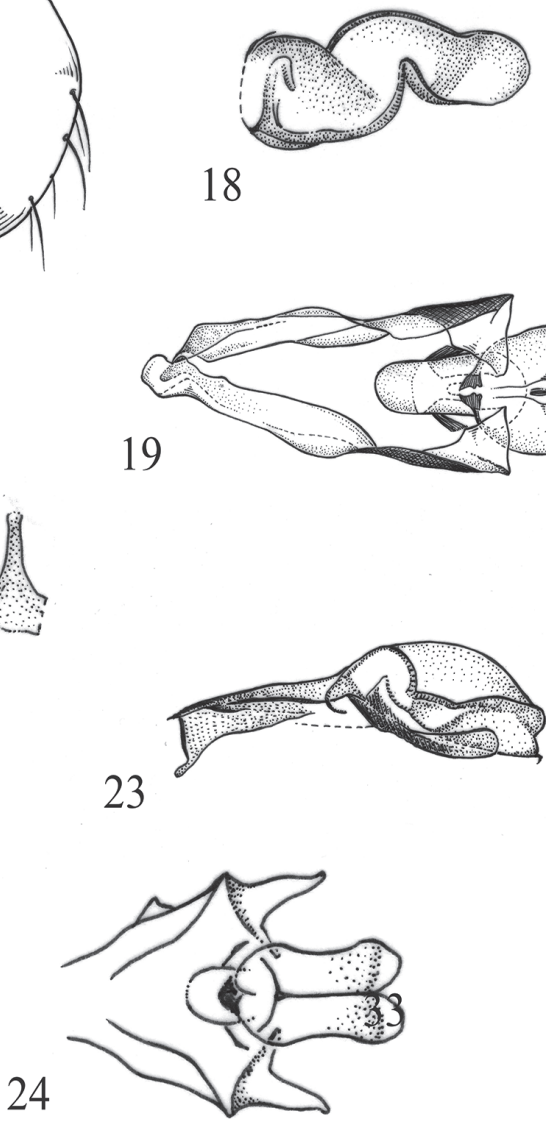

18

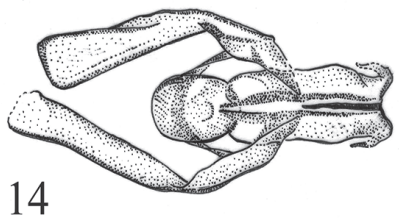

12

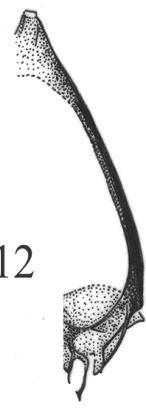

16
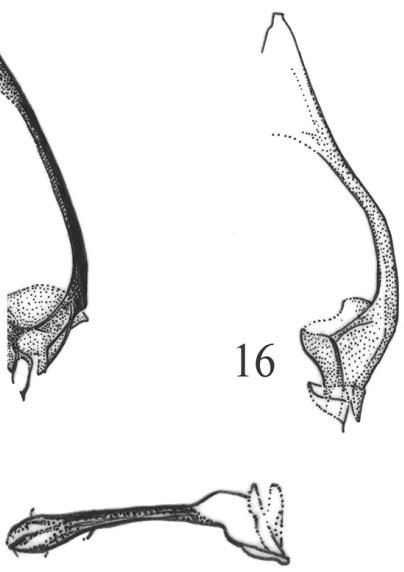

15

20
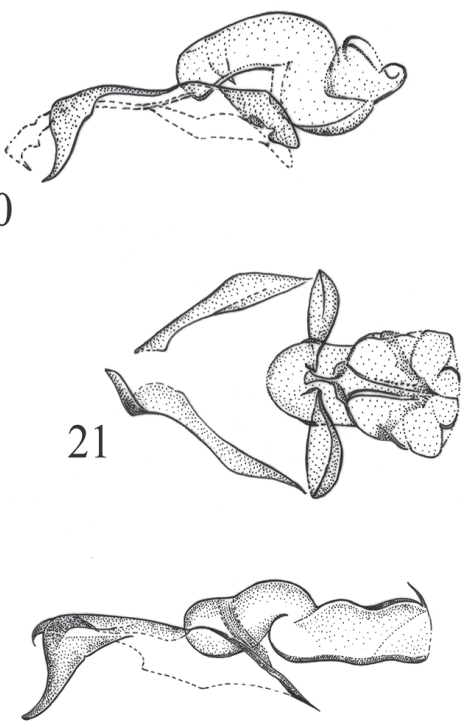

25

26

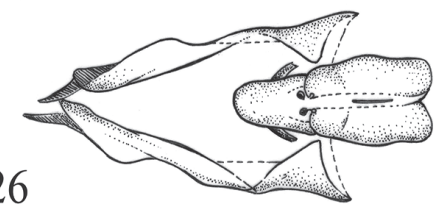

Figures (10-26) - Agromyza apfelbecki Strolb: (10) phallus; Agromyza fusca Spencer: (11) wing; (12) hypandrium; (13) phallus, lateral view; (14) phallus, ventral view; Agromyza simillima Spencer: (15) ejaculatory apodeme; (16) hypandrium; Agromyza parvicornis Loew: (17) surstylus; (18) phallus, lateral view; (19) phallus, ventral view; Agromyza animata Spencer: (20) phallus, lateral view; (21) phallus, ventral view; Agromyza venezolana Spencer: (22) hypandrium; (23) phallus, lateral view; (24) phallus, ventral view; Agromyza proxima Spencer: (25) phallus, lateral view; (26) phallus, ventral view (Fig. 10 modified from Spencer 1973a; Figs 11-16 modified from Spencer 1963; Figs 17-19 modified from Spencer and Stegmaier Jr 1973; Figs 20, 21 modified from Spencer 1973b; Figs 22-24 modified from Spencer 1963; Figs 25, 26 modified from Spencer 1969). 

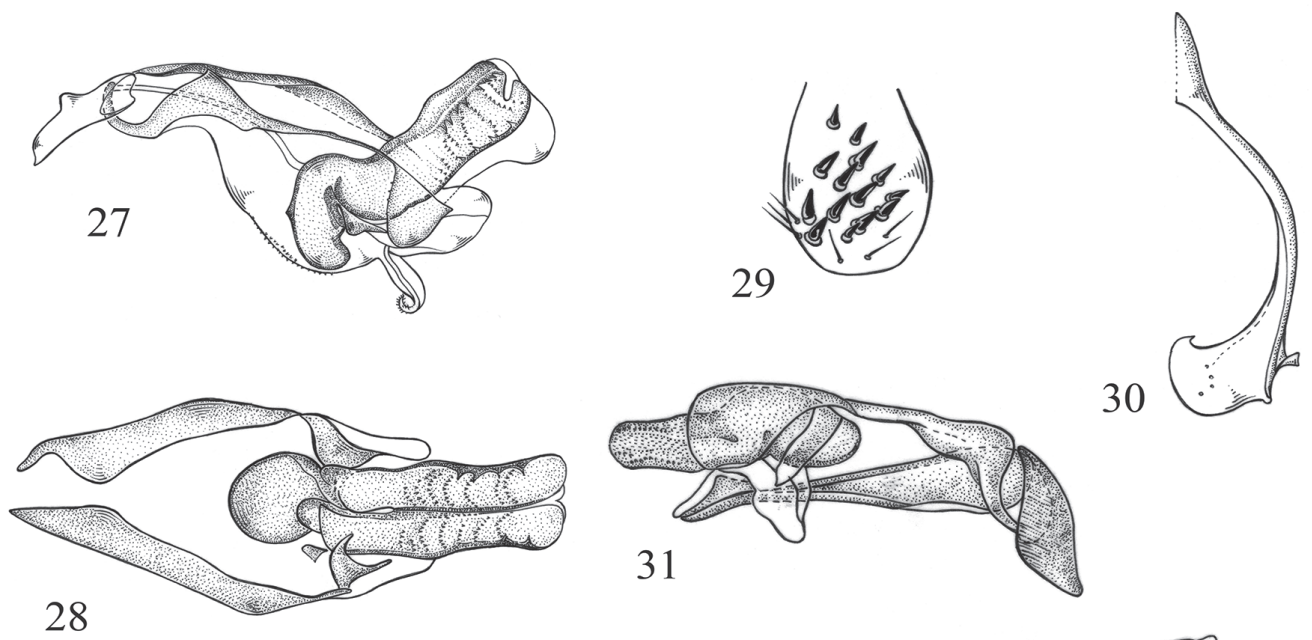
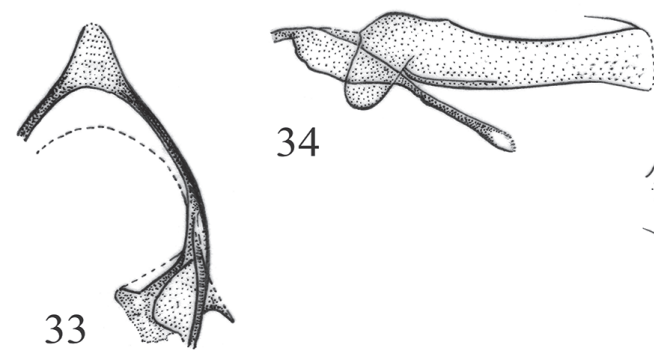

36

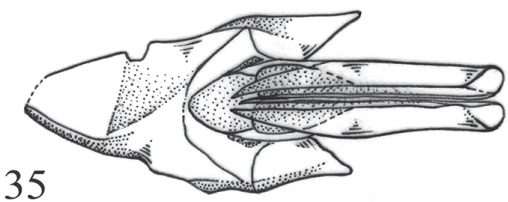

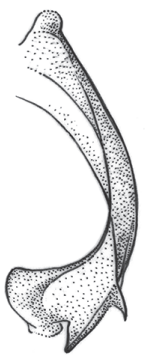

32

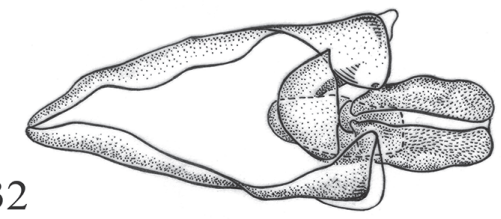

37

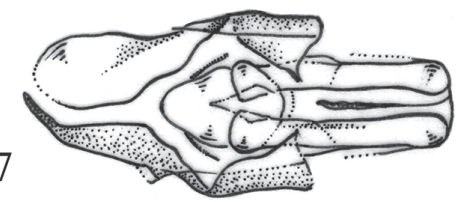

38

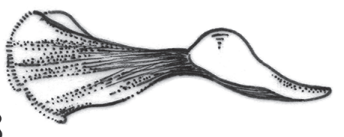

Figures (27-38) - Agromyza serratimentula Sasakawa: (27) phallus, lateral view; (28) phallus, ventral view; Agromyza megaepistoma Sasakawa: (29) surstylus; (30) hypandrium; (31) phallus, lateral view; (32) phallus, ventral view; Agromyza insolens Spencer: (33) hypandrium; (34) phallus, lateral view; (35) phallus, ventral view; Agromyza plaumanni Spencer: (36) hypandrium; (37) phallus, ventral view; (38) ejaculatory apodeme. (Figs 27, 28 modified from Sasakawa 1992; Figs 29-32 modified from Sasakawa 2005; Figs 33-38 modified from Spencer 1963).

\section{ACKNOWLEDGMENTS}

We would like to thank Dr. Carlos Lamas (Museu de Zoologia da Universidade de São Paulo) and Dr. Silvio Nihei (Instituto de Biologia da Universidade de São Paulo) for the opportunity to participate on the SISBIOTA project. We also thank Luiz Antonio Alves da Costa (Museu Nacional, Universidade Federal do Rio de Janeiro) for the final artwork of the drawings. We are also grateful to Dr. Daniel Whitmore, curator of the Department of Life Sciences in The Natural History Museum (London, United Kingdom) for the sending of some types images. Thanks also to the Conselho Nacional de Desenvolvimento Científico e Tecnológico (CNPq. process number 563256/2010-9) and Fundação de Amparo à Pesquisa do Estado de São Paulo 
(FAPESP) (Process number 2010/52314-0) for the support to the SISBIOTA Diptera Project. The authors are grateful for the financial supports (VRS: $\mathrm{MsC} / \mathrm{CNPq}$, process: 114102988; MSC: CNPq, process: 300382/2010-3). We also thank the anonymous reviewers for their substantial suggestions that improved the quality of the present contribution.

\section{RESUMO}

Agromyza Fallén (Diptera, Agromyzidae) é um gênero de moscas minadoras, com espécies que tem grande importância econômica. $\mathrm{O}$ conhecimento desse gênero é insuficiente no neotrópico, com 12 espécies conhecidas, apenas seis delas registradas para o Brasil. Esse artigo descreve duas novas espécies de Agromyza dos biomas Cerrado e Pantanal e registra três espécies representadas apenas por fêmeas, que não puderam ser identificadas em nível específico. Apresentamos também uma chave taxonômica para as 14 espécies assinaladas na região Neotropical. Os espécimes foram coletados nos estados do Mato Grosso e Mato Grosso do Sul e estão depositados nas coleções do Museu de Zoologia, Universidade de São Paulo e do Museu Nacional, Universidade Federal do Rio de Janeiro. Os adultos foram fotografados e as terminálias masculinas foram dissecadas e ilustradas.

Palavras-chave: Moscas minadoras, morfologia, novas espécies, taxonomia.

\section{REFERENCES}

BENAVENT-CORAi J, MARTINEZ M AND JIMENEZ-PEYdRO R. 2005. Catalogue of the hosts-plants of the world Agromyzidae (Diptera). Boll Zool Agrar Bachic Serie II 37: 1-96 Supplementum.

BezzI M AND TAVARES JS. 1916. Alguns Muscídeos Cecidogénicos do Brazil. Brotéria Ser Zool 14: 155-170.

BoUCHER S. 2010. Family Agromyzidae (leaf-mining flies). In: Brown BV, Borkent A, Cumming JM, Wood DM, Woodley NE and Zumbado M (Eds), Manual of Central American Diptera, Volume 2 National Research Council Press, Ottawa, p. 1057-1071.

CIVElEK HS, CiKMAN E AND DURSun O. 2009. Revised checklist of Turkish Agromyzidae (Diptera) fauna of Turkey. Turk J Zool 33: 349-358.

CUMming JM AND WoOD DM. 2009. Adult morphology and terminology In: Brown BV, Borkent A, Cumming JM,
Wood DM, Woodley NE and Zumbado M (Eds), Manual of Central American Diptera, Volume 1 National Research Council Press, Ottawa, p. 9-50.

ETIEnNE J AND MARTINEZ M. 2003. Les Agromyzidae de Guadalupe: espèces nouvelles et notes additionelles (Diptera). Nouv Rev Entomol (nouvelle série) 3: 249-272.

FRICK KE. 1959. Synopsis of the species of Agromyzid leaf miners described from North America. Proc U S Nat Mus 108: 347-465.

GIL-ORTIZ R, MARTINEZ M, FALCÓ-GARÍ JV AND JIMÉNEZPEYDRÓ R. 2010. Lista comentada de las especies de Agromyzidae (Diptera) citadas para Andalucía. Boln Asoc esp Ent 34(3-4): 307-321.

HENDEL F. 1931-1936. Agromyzidae In: Lindner E (Ed), Die Fliegen der palaearktischen Region 59: 1-570.

LOEW H. 1869. Diptera Americae septentrionalis indigena. Ibid 13: 1-52.

MARTINEZ M AND ETIENNE J. 2002. Liste systématique et biogéographique des Agromyzidae (Diptera) de la région néotropicale. Boll Zool Agrar Bachic Serie II 34: 25-52.

MARTinez M, ETIENnE J, ABUd-AnTUn A And REYes M. 1993. Les Agromyzidae de la République Dominicaine (Diptera). Bull Soc entomol Fr 98(2): 165-179.

SASAKAWA M. 1992. The Neotropical Agromyzidae (Diptera) Part 4: New or little-known species from Peru, Venezuela, Brazil and Bolívia. Sci Rep Kyoto Pref Univ Agr 44: 1-33.

SASAKAWA M. 2005. The Neotropical Agromyzidae (Insecta: Diptera) Part 6: New or little-known species from El Salvador and Guatemala. Spec Div 10: 151-169.

SCHEFFER JS, WINKLER IS AND WIEGMANN BM. 2007. Phylogenetic relationships within the leaf-mining flies (Diptera: Agromyzidae) inferred from sequence data from multiple genes. Mol Phylogenet Evol 42: 756-775.

SPENCER KA. 1963. A Synopsis of the Neotropical Agromyzidae (Diptera). Trans R Entomol Soc Lond 115: 291-389.

SPENCER KA. 1966. New and interesting Agromyzidae (Diptera) from Florida. Stuttg Beitr Nat kd 158: 1-20.

SPENCER KA. 1967. Family Agromyzidae. In: Papavero N (Ed), A catalogue of the Diptera of the Americas south of the United States. Departamento de Zoologia, Secretaria da Agricultura, São Paulo 17(III): 83.1-83.23.

SPENCER KA. 1969. The Agromyzidae of Canada and Alaska. Mem Ent Soc Can n. 64, 311 p.

SPENCER KA. 1973a. Agromyzidae (Diptera) of economic importance. Series Entomologica 9. W. Junk, B.V., The Hague, 418 p.

SPENCER KA. 1973b. Agromyzidae in Costa Rica. Beitr Ent 23: 151-156.

SPENCER KA. 1990. Host specialization in the World Agromyzidae (Diptera). Series Entomologica 45. Kluwer Academic Publishers, Dordrecht, 444 p.

SPENCER KA, MARTINEZ M AND ETIENNE J. 1992. Les Agromyzidae (Diptera) de Guadeloupe. Ann Soc Entomol Fr (NS) 28(3): 251-302. 
SPENCER KA AND STEGMAIER JR CE. 1973. Agromyzidae of Florida with supplement on species from the Caribbean. In: Arthropods of Florida and neighboring land areas 7: 1-205.

SPENCER KA AND STEYSKAL GC. 1986. Manual of the Agromyzidae (Diptera) of the United States. U.S. Department of Agriculture, Agriculture Handbook n. 638, $478 \mathrm{p}$.

STROLB PG. 1902. Neue Beitrage zur Dipterenfauna der Balkanhalbinsel. Glasnik Muz Bosn Herz 14: 504.

STROLB PG. 1906. Spanische Dipteren. Beitrag II Mem R Soc Esp Hist Nat 3: 380.
TSCHIRNHAUS M. 1971. Unbekannte Stridulationsorgane bei Dipteren und ihr Bedeutung fur Taxonomie und Phylogenetik der Agromyziden. Beitr Entomol 21: 255579.

VALLADARES GR. 1998. Primera cita del gênero Agromyza (Diptera: Agromyzidae) para la Argentina. Ver Soc Entomol Argent 57(1-4): 105-108.

ZetTerstedT JW. 1848. Diptera Scandinaviae. Lundae 7: 2728-2844.

ZLOBIN VV. 2000. Contribution to the knowledge of Agromyza species (Diptera: Agromyzidae) feeding on Leguminosae. Int J Dipterol Res 11(1): 37-45. 